\title{
The Production of Urban Space in Vientiane: From Colonial to Neoliberal Times $(1893-2020)$
}

\author{
Sivilay Keobountham \\ National University of Laos, Vientiane, Laos \\ Email: sivilaykt@gmail.com
}

How to cite this paper: Keobountham, S. (2020) The Production of Urban Space in Vientiane: From Colonial to Neoliberal Times (1893-2020). Open Access Library Journal, 7: e6696.

https://doi.org/10.4236/oalib.1106696

Received: August 7, 2020

Accepted: September 7, 2020

Published: September 10, 2020

Copyright $\odot 2020$ by author(s) and Open Access Library Inc.

This work is licensed under the Creative Commons Attribution International License (CC BY 4.0).

http://creativecommons.org/licenses/by/4.0/

(c) (i) Open Access

\begin{abstract}
Urban space in Vientiane has been produced and reproduced by different driving forces. Although this space has been examined extensively in academic literature, very few scholars have studied these production processes. The objective of this paper is therefore to: 1) investigate the history of the urban planning and development from the French colonial to the neoliberal periods; 2 ) analyze vision, policy and the major driving forces in the urban development; and 3) examine the main actors in the implementation of the urban development vision, including an analysis of who benefits from this process. The study uses qualitative and documentary research methodologies, to interview key informants. The result finds that the city has been restructured many times. The urban development vision has been adjusted to global development trends. Neoliberal policy has been applied as the major driving forces in urban development. Many urban projects use private investment and joint ventures between state and private enterprises, and between domestic and foreign companies. Property developers from China and Laos are the main actors in these projects. The projects cause some state agencies and communities are moved to resettle in the outskirts. The movement has both voluntary and involuntary patterns. Involuntary resettlement and its impact have been compensated by the private project developers. Beneficiaries from this process can be summarized as follows: 1) Direct beneficiaries include the state, capitalists and upper-class households; and 2) Local people, especially middle- and lower-classes have benefited indirectly from improved infrastructure services. However, private companies have monopolized their economic interests on public land based on frameworks of concession contracts.
\end{abstract}

\section{Subject Areas}

Political Economy and Urban Studies 


\section{Keywords}

Urban Space, Political Economy, Neoliberalism, Vientiane

\section{Introduction}

The production of urban space is a political economy process that relates to several players-whether local, national, transnational and global organizations. These actors have shaped much landscape transformation of human settlement. The shift is generally positive results for economic growth, poverty reduction, and livelihood security. However, urbanization is not the result of natural processes but the consequence of actions and decisions by those who have economic or political power (Hiller, 2004) [1]. These acts are instrumental in capital accumulation and surplus absorption by capitalist elite while "the exercise of a collective power over the process of urbanization" is reversed (Haque, 2012) [2]. Some scholars claim that urbanization is a significant outcome of cooperation between the state and private sectors. It is a social duty of a state to improve the quality of life of its citizens. However, this is no more viewed as mere social functions but also as material outcomes of complex political-economic processes that are multiple and overlapping (Smith, 1984 [3]; Soja, 1989) [4].

Vientiane, the capital of Laos is an urban space that has been produced and reproduced by different driving forces. In the colonial era, the city was planned and developed by French colonial authorities for social reconstruction. In the post-colonial age, it has been further planned and developed by Lao authorities to provide livelihood security for its population. Nevertheless, Vientiane has still witnessed limited urbanization. Most of the city's population still cannot access efficient infrastructure services. According to (UNDP, 2020), Vientiane suffers from the lack of adequate drainage and sewerage systems, and the poor design of existing sewerage disposal or septic tanks [5]. Moreover, Vientiane still depends on foreign direct investment, official development assistance and loans to sustain its socio-economic security. These issues have pressured the urban governors to have gradual incorporated neoliberal ideas into the formulation of the urban development policy.

The policy encourages all economic sectors both domestic and foreign for the urban development. Consequently, many agency buildings, office buildings, commercial centers, hospitals, hotels, apartments, townhouses and other buildings have been newly constructed and repaired throughout the city. Some projects are private investment both domestic and foreign companies. However, in the midst of increased investment, there are some local inhabitants and state agencies are moved from central areas to resettle on the outside of the city. The process is instigated by the state authorities with the aim of promoting investment into new urban property within the core. Some projects have resulted in the transfer of land ownership from once social class to another. 


\section{Literature Review}

\subsection{The City and the Urban as Spaces of Social Production}

In ancient times, a city was described as a large site of human settlement. It was generally surrounded by a high wall and a moat to protect it from outside forces. The process is commanded by a hegemonic class as a tool to produce its own social space. Nonetheless, the concept of city development has changed to align with trends in global development. A city has currently been defined as an important habitation, with a high population density carrying a demand for efficient infrastructure services. According to Castell (1977) [6], the city was as a space of social construction. Its spatial expression is dialectic between production, services, consumption, exchange, and administration.

The city and urban areas are defined in different ways. Some scholars identify the city as a site of modernity, where people live and work in proximity to each other. It is a space that facilitates interaction between people and commerce, with potential to benefit both parties, although also presenting challenges within processes of urban growth (James et al., 2013) [7]. While, urban areas are defined as designed space for social development. It consists of a density of human structures such as roads, houses, commercial buildings and various facilities. Urban areas are categorized into metropoles, cities, and towns, generally based on size, density and level of infrastructure. Its modernity is driven by the process of urbanization. Castells (2002) analyzed the formation of the new urban world as the emergence of a new society, which is a consequence of the interaction between the information-technology revolution, socioeconomic restructuring, and social movements [8].

Through the analysis above, the city is a site of social formation, and multi-sector investment represents a means to reduce social inequality (Harvey, 2000:9) [9]. Thus, the city development is a significant process of social construction. However, the process seems the struggle over resources among urban residents, property developers, social classes and different groups. At the same time, it seems the points of contradiction and conflict between capital accumulation and social redistribution, between state control and people's autonomy. Thus, state control of social services and public amenities became the key element in the organization of both everyday life and urban processes (Castells, 2002) [8]. As a result, cities are transformed by the interface between electronic communication and physical interaction, by the combination of networks and places. These cities are sites of spontaneous social interaction that derive from the process of globalization (Castells, 1989 [10]; Sassen, 1991 [11]). The cities are currently controlled by information and communication technology (ICT) to enhance the quality of living for its citizens through the performance of urban services like closed circuit television. According to Sassen (2005), the large cities of today emerge as the process of the network society, which is powered by ICT [12].

\subsection{Political Economy and Urban Development Planning}

The notion of political economy has been applied as the crucial element in urban 
development planning in contemporary world, especially the relevance of neoliberalism. This doctrine is an economic development theory emphasizing the role of the private sector in infrastructure construction to reduce government expenditure. Some projects called public-private partnership. This partnership is a basis for enhancing the living standards of populations (Shi and Yu, 2012) [13]. Nevertheless, neoliberalism emphasizes a free market and equitable competition in the production of goods and services, including urban space. The process values privatization and deregulation in the spatial organization of a city. This policy helps many countries have succeeded in providing economic resources and infrastructure services such as UK, USA, Singapore etc. Nonetheless, the policy has resulted in the centralization of wealth and power in the hand of a few by dispossessing the public of their wealth or land (Harvey, 2004) [14]. The policy is criticized as centralizing access to capital and power for a political elite and the middle classes. These classes can get access to the margins of modernized space and services, while the lower class is pushed to resettle outside the city.

Neoliberalism is an instance theory of political and economic practice that proposes that human well-being can the best advanced by liberating individual entrepreneurial freedoms within an institutional framework (Harvey, 2005) [15]. It witnessed the success in Chinese urban development. The success derives from three impulses: 1) Governmental or quasi-governmental impulses, which consist of a) external forces (e.g. FDI, WTO, WB, etc.); b) National domestic forces (e.g. the national state): national forces working with globalization and sub-national partners to advance the goals of national development; and c) Regional (e.g. provincial): at these levels authorities are vigorously competing to attract global forces particularly in the coastal zones that are accelerating the processes of urbanization sub-regional; 2) Entrepreneurial impulses: a) bureaucratic entrepreneurs and b) private sector entrepreneurs; and 3) Popular sector entrepreneurship: a) Individual households and b) small-scale collective entrepreneurs (McGee, 2009) [16].

At the same time, the success is considered as the result of transition from managerialism to entrepreneurialism, central planning to market coordination, and state monopoly to decentralization. It is the processes driven by globalization, national policy and local bureaucratic entrepreneurial initiatives (MeGee et al., 2007) [17]. This transition is considered as the result of transition from peripheral socialism to the margins of global capital. It has offered significant opportunities to increase the economic prosperity and social well-being of urban residents (Tsenkova, 2006) [18]. While, urban development planning is a process of spatial reorganization. It began with the establishment of SEZs. However, urban development planning is acknowledged as a project planned, guided and implemented by the central government with the participation of local government, quasi-government agencies, the private sector and foreign investment (McGee et al., 2007: 77) [17]. Zhang (2001) similarly sees the rapid transition of cities as a result of the change from a socialist state economy toward the liberal 
market economy. This is a consequence of the change in state power relations and social networks. It is a response to both market conditions and institutional legacies from the centrally planned economy [19].

\section{Analysis and Results}

\subsection{The History of Urban Planning and Development in Vientiane}

In Vientiane, the notion of urban planning was first introduced by French colonial authorities in the late $19^{\text {th }}$ century (Hayward, 2017 [20]; Manotham, 2010 [21] and Sayarath, 2005 [22]) and the city has been restructured many times since then: from 1900-1920, 1920-1940, 1940-1950s, 1990-2000 and 2000-2010s. Lately, JICA (2011) presented a new urban master plan, which is targeted towards the year 2030 [23]. During the era when Vientiane was part of a French Protectorate, three periods of urban planning were formulated (1900-1920, 1920-1940 and 1940-1950s). The plan specified land use zoning along areas of the Mekong river bank. It shows land use categorization among official, residential, temple and stream zones (Figure 1). Later, the French colonial authorities improved and paved the way for new city infrastructure (Sayarath, 2003) [24]. The city was surrounded by a high wall and a moat (Figure 2).

From the 1900s to the 1950s, Vientiane urban plan concerning road construction and public works was implemented as main activities (Insisiengmai, 2018) [26]. The process was divided into three periods: 1) from the 1900s to the $1920 \mathrm{~s}$ there were construction of roads, governmental offices and zoned residences, and Buddhist temples ( Wat) in inner urban areas; 2) from the 1920s to the 1940s roads were constructed systematically in inner urban area and along the wall of the city; and 3) from the 1940s to the 1950s new roads were constructed both in

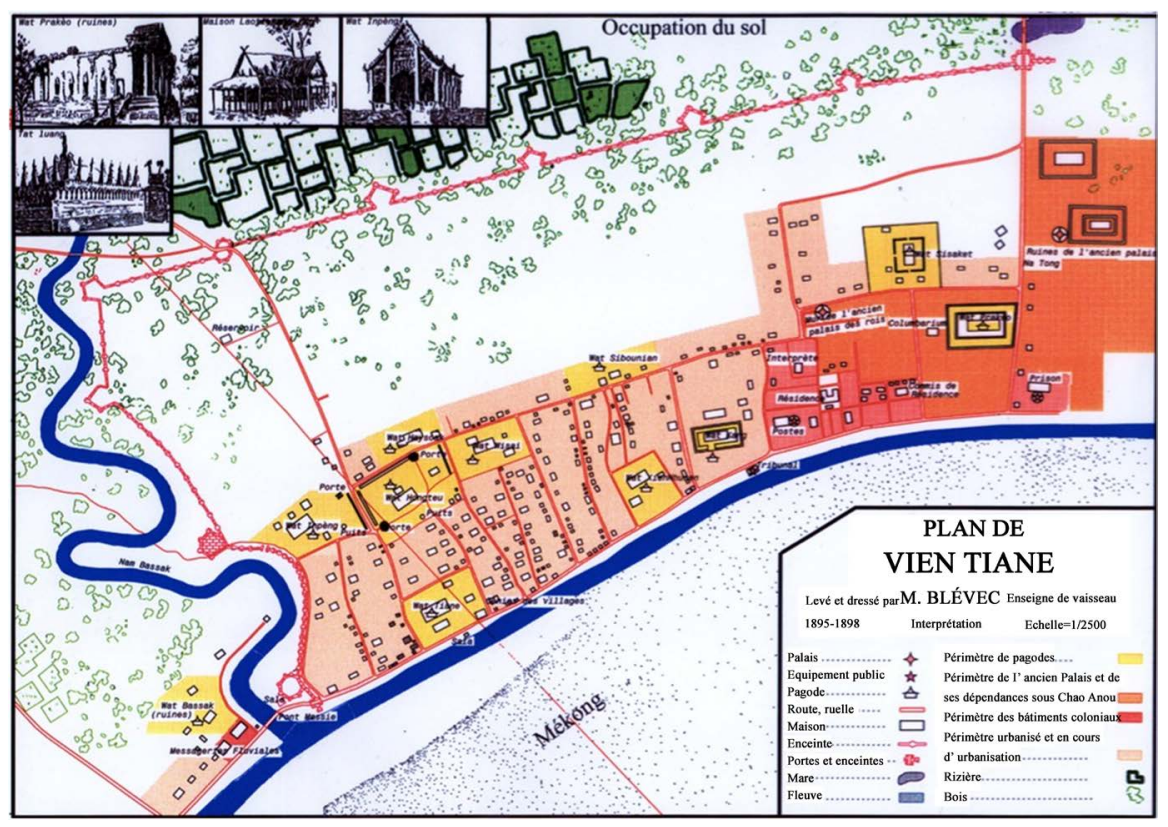

Figure 1. Urban Vientiane Map, drawn by Official and Residential Zones in 1910 (original). (Source: Manotham, 2010 [21] and Sisourath, 2003 [25]). 


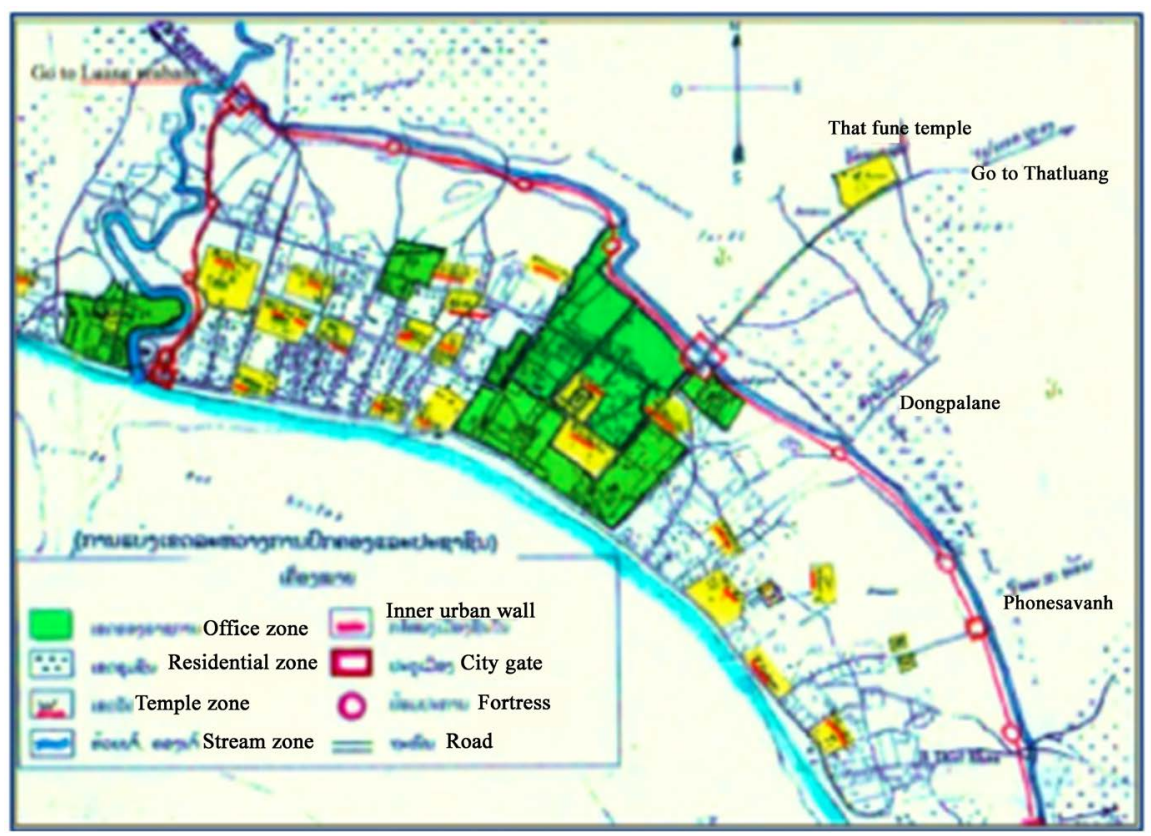

Figure 2. Land categorization between Le Blévec 1895. (Source: Manotham, 2010 [21] and Sisourath, 2003 [25]).

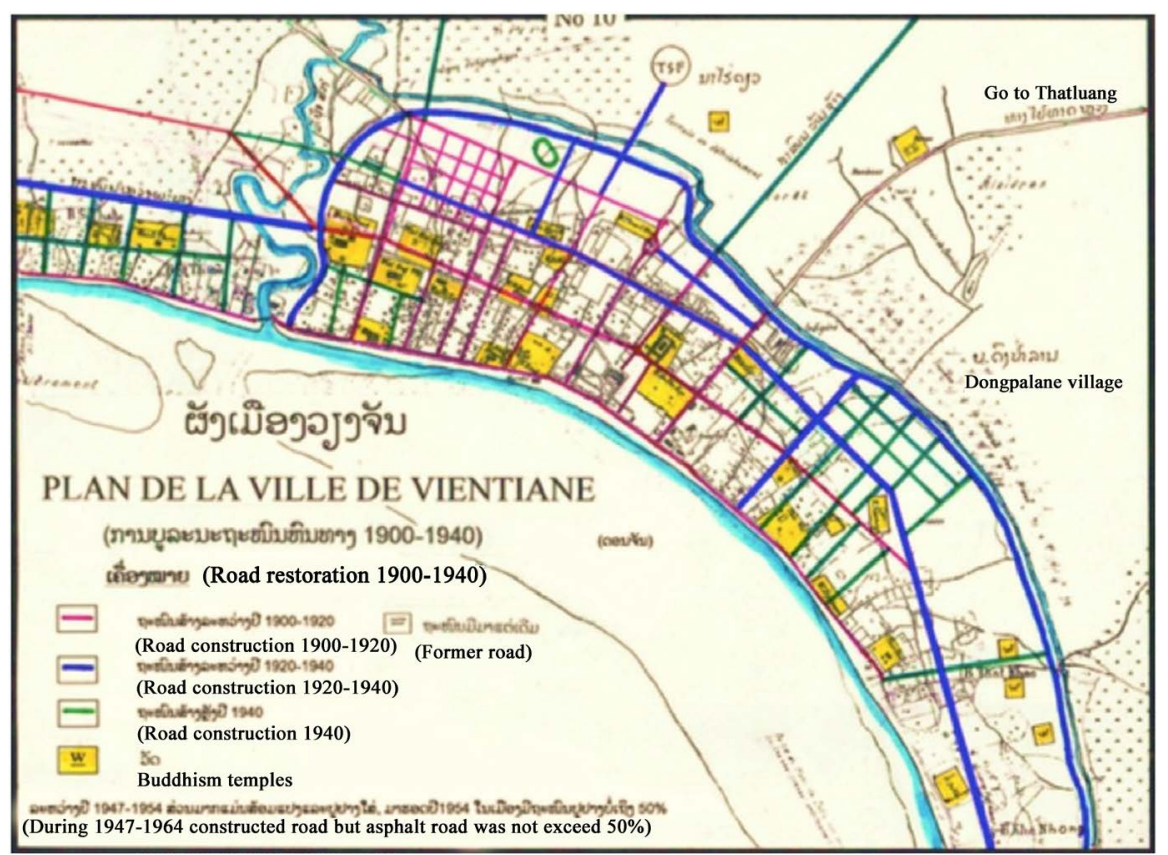

Figure 3. Vientiane Masterplan 1900-1940. (Source: Manotham, 2010 [21]; adapted by author).

inner and outer urban areas, including Land Xang Avenues (Figure 3). From the 1940s up to 1958, the city expanded outside the historic outer wall (Choummanivong, 2018) [27]. The presence of a grid system of streets represents a clear influence of French colonization. The central part of the city also contained avenues with many colonial buildings. The urban area comprises Wat areas which are marked with a yellow-red colour, residential zone is marked with grey colour 
and official zones in green are seen to dominate a large part of the city.

Roads outlined in dark-red colour were constructed within the inner urban area between 1917 and 1930 (Figure 4). Red coloured roads were constructed between inner urban and outer urban zones (Sithan, Oumong and Khounta villages) from 1930 to 1950 . The green colour indicates road construction from Patouxai to That Luang, Phonkheng, Dongpalan and Phonsavanh villages from 1950 to 1960 . The urban planning and development process in Vientiane can be divided into three periods: 1) between 1905 and 1953 is under the colonial authorities; 2) between 1953 and 1974 is under control of the royal government and 3) from 1975 until the present is under control of the government of the Lao PDR. The process identifies different periods of urbanization, restructuring and specific development areas during the twentieth century. From 1996-2000, the urban area covered only 100 villages. From 2000-2010, the city area was expanded from 20,950 to 61,600 hectares (or 150 villages) and future urban areas is around 189 villages (Figure 5).

According to the urban plan covering the period 2000-2010, Vientiane is categorized the urban land use system into six zones: 1) The historic conservation zone; 2) The inner urban zone; 3) The outer urban zone; 4) The sub-center zone; 5) The outskirts zone; and 6) The urban cluster zone (Figure 6). Following the plan, the whole Vientiane area is categorized under a multi-core structure with careful consideration of the current situation in each locality (Figure 7). The aim is to induce an appropriate spatial use and restrict inappropriate construction to achieve the livable urban development vision in 2030. This notion is designated in the urban planning law (2017), to be a statutory tool for the state to

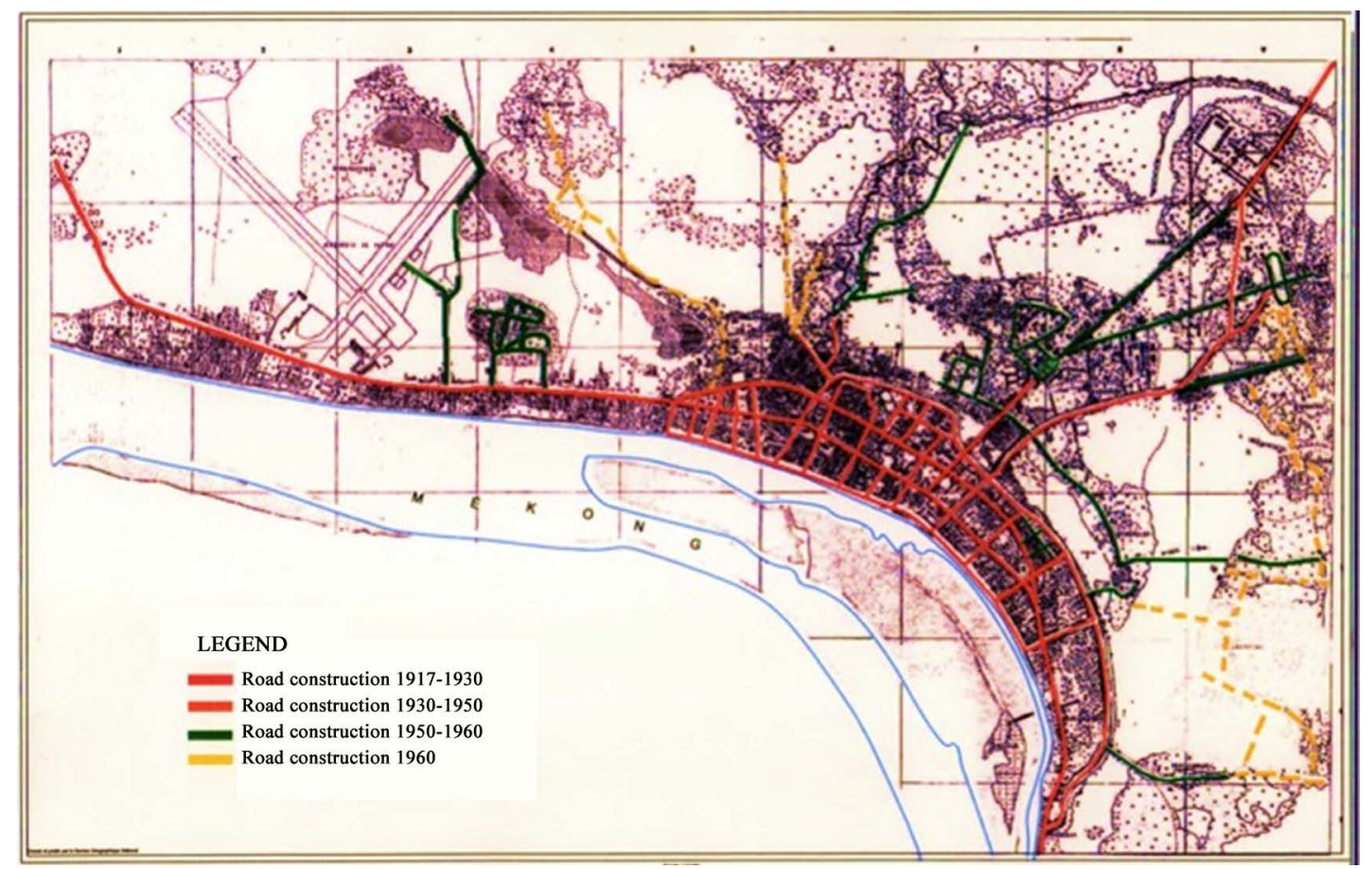

Figure 4. Road network development (1917-1960). (Source: Sisourath, 2003 [25]; adapted by the author). 


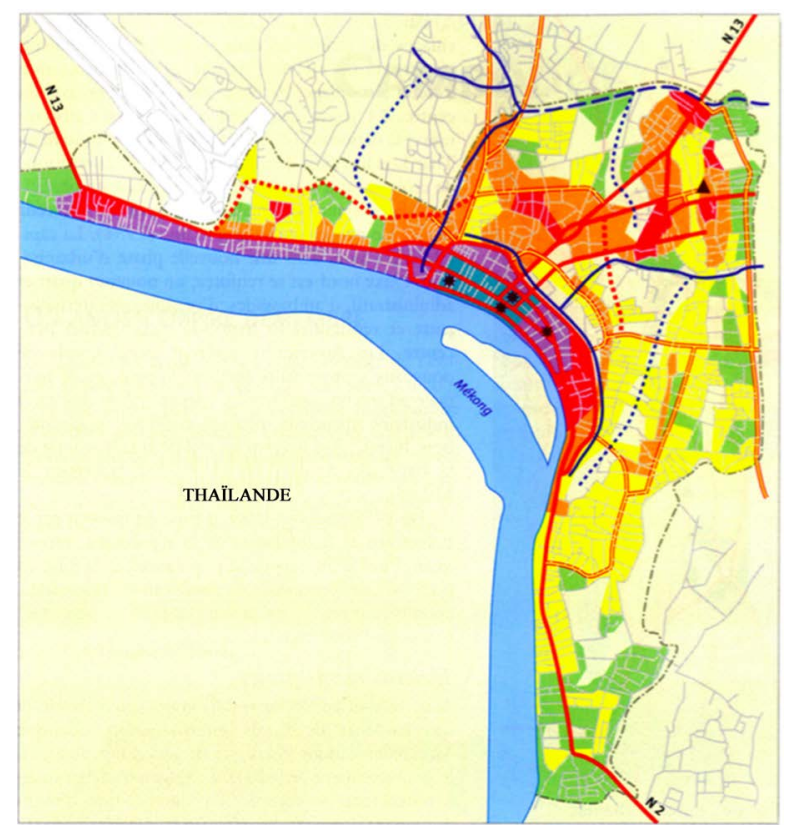

Figure 5. Urbanization process. (Source: Sisourath, 2003 [24]; adapted by the author).

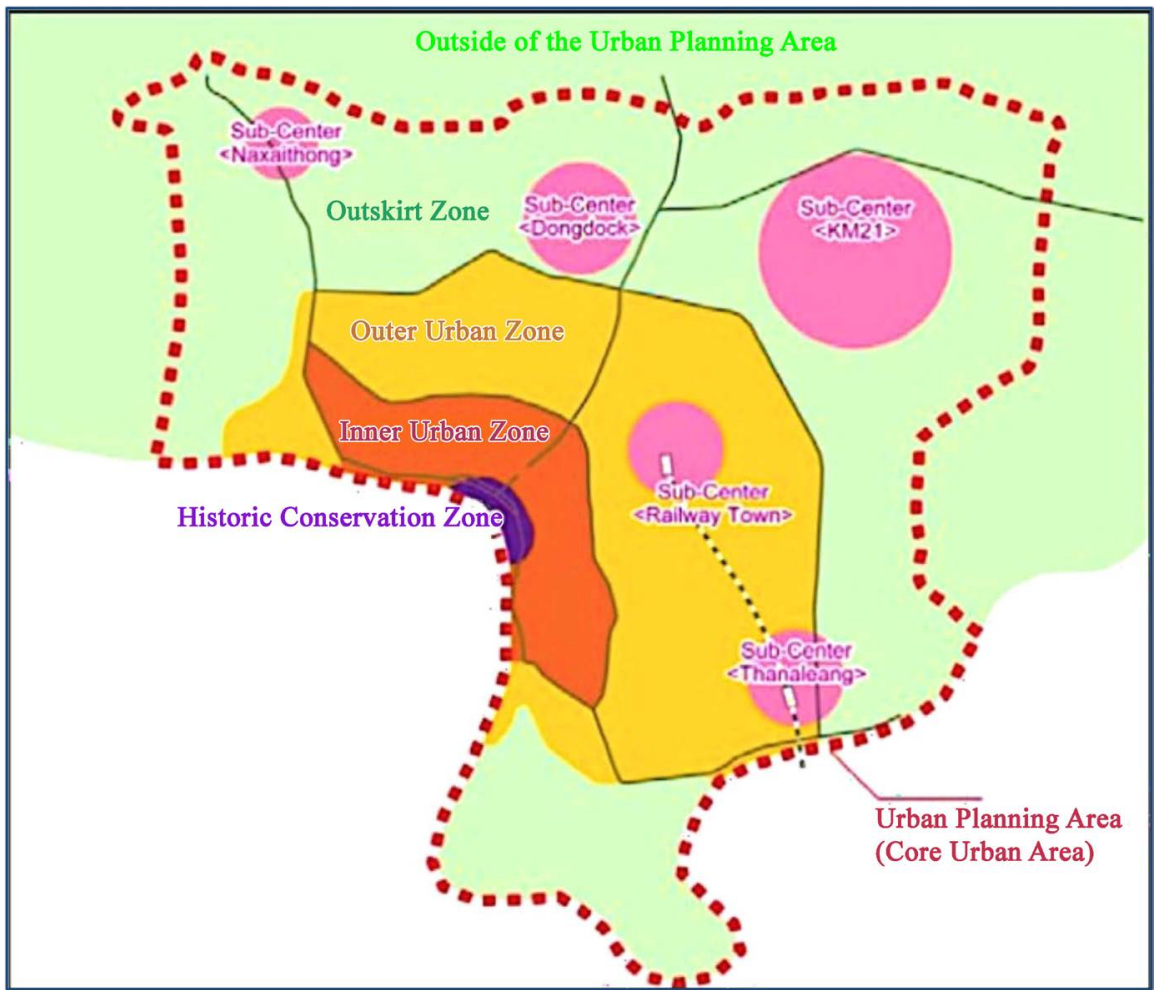

Figure 6. Zoning the urban planning area. (Source: JICA, 2011 [22]).

promote investment towards the path of sustainable urban development (Phouvong, 2018) [28].

The multi-core structure in the 2011 master plan aims to control the expansion of an existing urban center, and avoid over-concentration, through the creation of sub-centers and urban clusters. The plan extends the urban area from a 


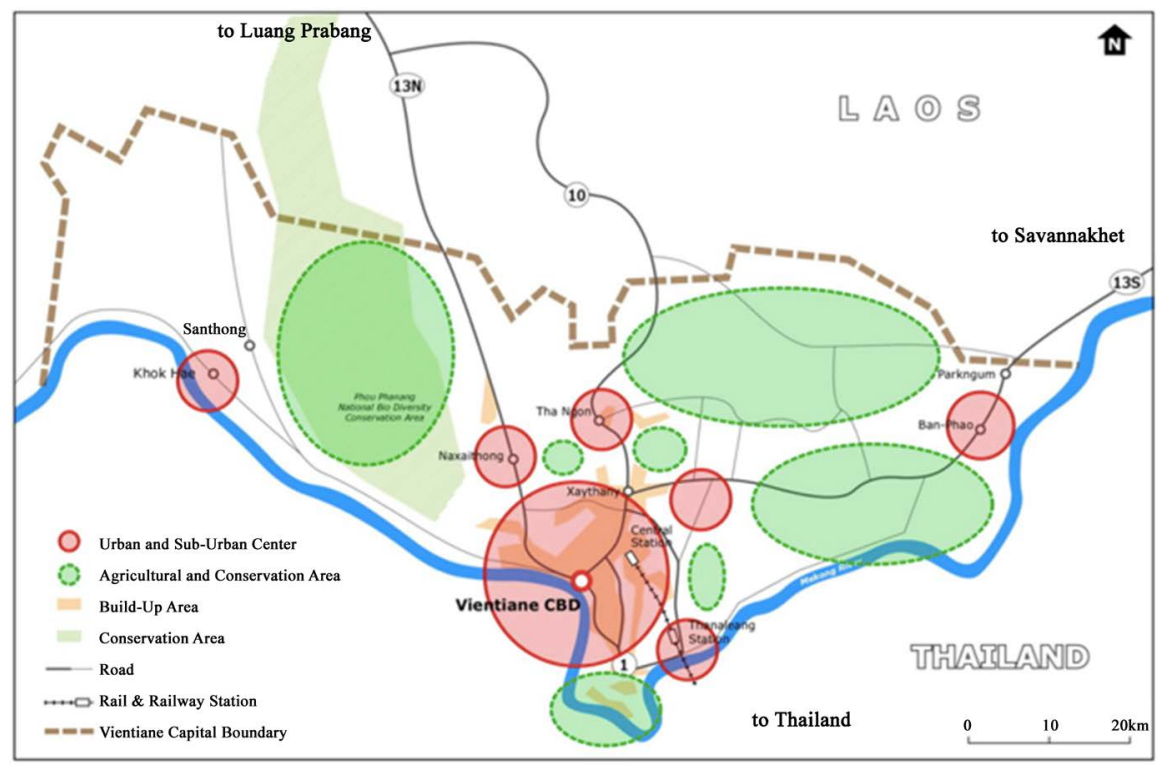

Figure 7. Concept of a multi-core structure.

radius of approximately 5 to $10 \mathrm{~km}$, centerd around Patouxai. The plan calls for an extension of the urban area along national and newly-constructed roads: Kaison; R10; Nongbeuk and 450 Year Roads. It is stipulated that a future development plan will propose a road to link the inner and outer urban zones and sub-centers. Furthermore, the plan also details agricultural, conservation, and built-up areas. Nonetheless, the urban area has started to expand outside the core urban area and sprawl outward into the surrounding farmlands. Some urban area is characterized by sprawl into the lands that were previously used as forests (Sharifi et al., 2014) [29].

According to the 2011 plan, two ring roads have been constructed to connect transport between the inner urban area, the urban center, the sub-center and outer urban zones. This includes the new urban areas: 1) Khampheng Mueang Road to T4 Roads and 2) Thanaleang to Naxaithong district via the 450 Year Road. At the same time, four roads have been constructed to link different areas of the city, as follows: 1) West road linking the urban center to Khok Hae; 2) East road linking the center to KM21 and Ban Pao via Railway town; 3) North road linking Dongdok to Thangon villages; and 4) South road linking the urban center to Thanaleang village. The plan also looks to the construction of New Vientiane International Airport, which will serve as a replacement for the current International Airport.

\subsection{Development Vision of Vientiane in the Future}

The development vision of Vientiane was first initiated in 2005 by the $4^{\text {th }}$ Party Committee of Vientiane Administrative Authority. It is intended as a significant direction in the urban development. The vision comprises three following goals: 1) To build Vientiane to become a "livable city", which defined as the development of Vientiane to become a peaceful, green, lean, light, charming and pros- 
perous city; 2) For the second vision, to build Vientiane as a "sustainable city" aims towards durability against natural disasters and sustainable livelihood development for urban residents. The guide to implement this vision involves: a) prepare housing, public facilities and basic infrastructure services; b) use local materials, encourage energy saving and use renewable energy; c) urban planning to save travel, promote travel by public transportation systems; d) reduce poverty through small-scale enterprises; e) reduce migration from rural to urban areas; and f) settlement must reduce risk from natural disasters; 3) To build Vientiane to become eco-city, which looks towards balance among economic and social development, and natural environmental protection. It includes the preservation of agricultural land to produce food for the population, wetland, and the conservation of green space to maintain biodiversity (Vientiane Administration Office, 2015) [30].

The vision represents the first conceptual adjustment of the Lao elite and urban planners to global development trends, especially principles of sustainable development. The vision is then reset by Japanese study team following terms: 1) build Vientiane to become a regional hub in the Great Mekong Sub-region (GMS); 2) build Vientiane to become a center for the nation; and 3) build Vientiane to become comfortably-livable and beloved hometown for all (JICA, 2011) [23]. These reformulated visions are consistent with the strategy of transforming Laos from a landlocked to a land-linked country, ensuring a transition to sustainable development over the next 20 years. The visions have been supported by the government to enhance connections with the countries in GMS.

\subsection{Neoliberal Policy as the Driving Force in Urban Development of Vientiane}

Urban problems are becoming an essential element in the policies of government and the everyday life of a large population (Castells, 1977) [7].

Since the 2000s, neoliberal policy is applied as the driving force in urban development process of Vientiane. Investment through PPPs, BOT, BTO, BOO, BOOT and BOOST are used for the private sector to seek capital sources, and design, construct and provide infrastructure services. Aphaylath (2017) claimed that the state has encouraged all sectors of economy and society to participate in the city development process [31]. Concurrently, Lao urban planners also drafted a master plan to develop Vientiane until 2030 in the belief that new policy will attract more capital sources into urban development. The state sees this as a means to stimulate urban growth and to upgrade the quality of life of its citizen and visitors. Lengsavad (2013) claimed that the development of Vientiane should produce a beautiful, civilized and modern city. This demands a large amount of capital yet the government does not possess enough money. If borrowing money from abroad, interest must be paid. Indeed, Laos still carries much foreign debt. As a result, the government considered that Laos could use pieces of land to accelerate urban development. The cabinet thus approved the granting of state land concessions to the private sector for urban property de- 
velopment. He also explained that this is necessary for accelerating development of Vientiane [32]. As a result, many urban development projects in Vientiane that have derived from neoliberal policy. Some projects have been driven through granting economic land concessions. According to official information, since the 2000s many large-scale urban development projects have been approved and are being implemented in Vientiane as shown in Table 1.

Most of these projects involve real estate development for both rental and sale to new residents and visitors. The projects use private investment and joint ventures between state and private enterprises, and between domestic and foreign companies involving economic land concessions. For some projects, the government has provided land-use rights to developers or individual users by tender, auction or concession contract (see Table 1). Private sector investment both local and foreign has played a significant role in the implementation of the urban development vision. Bannavong (2017) mentioned that capital sourced from both the domestic and foreign private sector is a significant factor in this development process. In 2015, Vientiane approved 6.670 projects at a value of 9,66 billion US\$ for urban development. While public sector investment is playing a substantial role [33]. According to Nolintha (2011), investments (both domestic and foreign) play an important role in pushing the urban economy of Vientiane. The city has witnessed rapid development, fueled by government investment as well as domestic and foreign private investment [34].

Table 1. Large-scale urban real estate development projects in Vientiane.

\begin{tabular}{|c|c|c|c|c|c|}
\hline Project name & $\begin{array}{l}\text { Concession } \\
\text { area }(\mathrm{h})\end{array}$ & $\begin{array}{l}\text { Concession } \\
\text { period }(y)\end{array}$ & $\begin{array}{c}\text { Private } \\
\text { Developer }\end{array}$ & Joint Venture (shareholding) & $\begin{array}{l}\text { Investment } \\
\text { Value (US\$) }\end{array}$ \\
\hline 1. That Luang Marsh & 365 & 99 & Chinese & - & $1,600,000,000$ \\
\hline 2. Xaisettha Eco-City & 410 & 70 & - & Lao govt $25 \%$ and Chinese $75 \%$ & $365,000,000$ \\
\hline 3. "Vientiane New World" (VNW) & 42 & $50+40$ & - & Lao and Chinese & $600,000,000$ \\
\hline 4. Vientiane Sky City & 4.5 & - & - & Lao govt $51 \%$ and China private $49 \%$ & $320,000,000$ \\
\hline 5. Nongtha Paradise & 74.85 & 50 & - & Lao and Viet govts & $80,000,000$ \\
\hline 6. South Nong Chan 1 & 25 & 50 & Chinese & - & $180,000,000$ \\
\hline 7. South Nong Chan 2 & 10,60 & 70 & - & Lao $26 \%$ and China private $74 \%$ & $50,000,000$ \\
\hline 8. Nong Chan 3 & 11.14 & 70 & Lao & - & $30,000,000$ \\
\hline 9. Nong Ping1 & 100 & 70 & Lao & - & $50,000,000$ \\
\hline 10. Nong Ping2 & 100 & 50 & Chinese & - & $50,000,000$ \\
\hline 11. Vientiane Center & 5.34 & 50 & - & Laos $40 \%$ and China $60 \%$ & $75,000,000$ \\
\hline 12. Landmark Mekong & 5.34 & 90 & Lao & - & $75,000,000$ \\
\hline $\begin{array}{l}\text { 13. Shopping Mall and } \\
\text { 14. Office Building }\end{array}$ & 0.76 & 70 & Lao & - & $47,500,000$ \\
\hline 15. Nong Bua Mai New Modern City & 29 & 50 & $\begin{array}{c}\text { Chinese } \\
\text { (HK) }\end{array}$ & - & $50,000,000$ \\
\hline
\end{tabular}

Data collected from Division of Planning and Investment (2017). 
The process has significantly affected change in the cityscape, land tenure and land use in inner urban zones and along main streets. Example: real estate development at Nongchan wetland. In the past, local residents used to view this area as a large empty space with nothing exciting going on. Today it has been turned into the biggest and most luxurious shopping center in Vientiane (see Figure 8). At the same time, many pieces of wetland had been utilised for the housing, commercial centers, hotels, tourism sites and other developments such as That Luang marsh, Nong Chan, Don Chan, Nongtha, Nong Bua and Nong Bone (see Figure 9). Those are a key part of the urban development and expansion of Vientiane. The state expects that all projects will help modernize Vientiane. Those do not only boost growth of the urban economy but also contribute towards

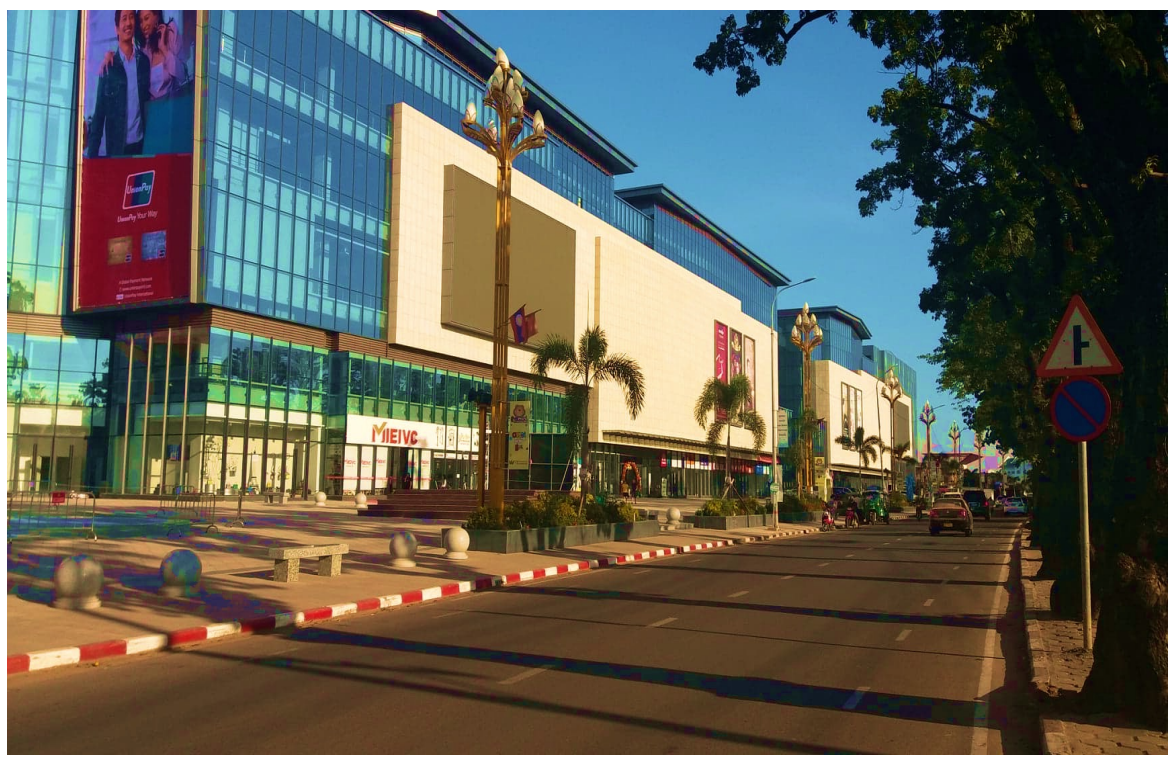

Figure 8. Change of the cityscape and land use along Khouvieng Road.

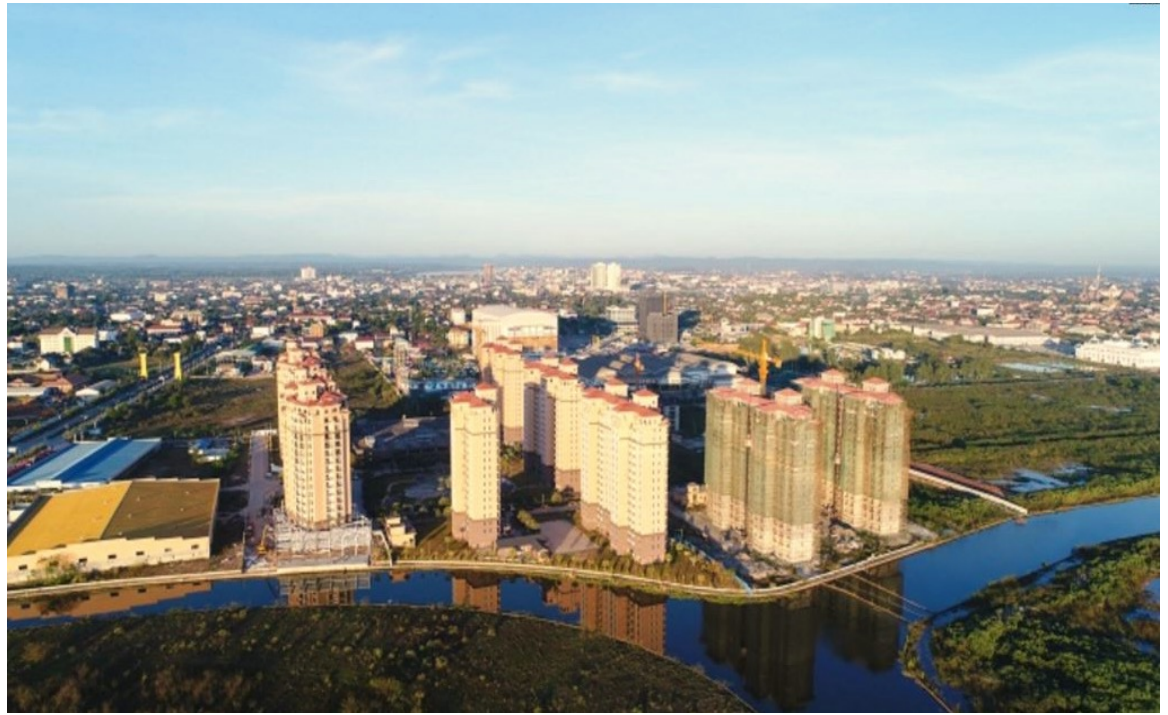

Figure 9. Urban real estate development at Tatluang Lake SEZ invested by Chinese property developer. 
improved social interaction and everyday lives of local people.

\subsection{Turning Land into Capital: The Driving Forces in Developing Vientiane}

Turning land into capital (TLIC) is a policy for generating revenue and economic value from state land (Pathammavong et al., 2017) [35]

Converting land into capital in Vientiane is an economic policy that utilizes natural resources for urban development. The policy was first implemented when Laos hosted for the Southeast Asia Game in late 2009, constructing a sports complex and guesthouses for athletes. The policy was implemented through the granting of land concessions to private corporations. The policy also has been applied through the construction of the 450 Year Road. This road has been implemented by reserving $50 \mathrm{~m}$ of land on either side of the road for sale to cover the cost of construction. Local authorities purchased land along both sides of the road from local residents and set it aside for sale to businesses upon its completion. Khoudphaithoun (2016) said that the policy of turning land into capital is a new issue. There do not exist clear mechanisms and regulations to support an implementation process. Thus, the policy is both implemented and conceived at the same time. It includes three road construction projects and five land deal projects have been implemented by local government. At the same time, Vientiane also has ten relocation projects of ministry buildings implemented by the government. He said that this policy is not better than state investment but is necessity for urban while the government lacks capital to invest itself. If the country has sufficiently developed, the policy can then be adapted [36]. Similarly, Malabandith (2015) added that the policy of turning land into capital adds value to land through its exploitation as a potential income source for the national budget [37].

Following this policy, there are some state agencies have been relocated to suburban and outskirt areas (see Table 2). Similarly, some urban communities have been relocated from urban sites such as villagers from Don Chan, Nongchan,

Table 2. Land deal projects between state agencies and private firms.

\begin{tabular}{ccccccc}
\hline State agency & $\begin{array}{c}\text { Private } \\
\text { company }\end{array}$ & $\begin{array}{c}\text { Original location village } \\
\text { and area }\left(\mathrm{m}^{2}\right)\end{array}$ & $\begin{array}{c}\text { New location } \\
\left(\text { Road/area } \mathrm{m}^{2}\right)\end{array}$ & $\begin{array}{c}\text { Investment } \\
\text { Value (\$) }\end{array}$ \\
\hline National library & Chitjalean & Xiengyeun & 3362 & Kaisone & 11,786 & $5,000,000$ \\
National museum & Khamphai & Anou & 29,600 & Kaisone & 4480 & $10,000,000$ \\
VDICT & TK Group & Xiengyeun & 3026 & Nong Beuk & 10,000 & $11,000,000$ \\
PCCPTB & Kolao & Nongbon & 3273 & Kaisone & 6000 & $9,000,000$ \\
LFTU & Ramayana & Hadsadi & 3481 & 450 Y Road & 11,230 & $10,000,000$ \\
MLSW & Asia & Xiengyeun & 3747 & R10 & 40,000 & $12,000,000$ \\
LNTA & Dao Heuang & Xiengyeun & 2482 & 450 Y Road & 20,000 & $12,500,000$ \\
MOJ & Sisangvone & Thatfeun & 24,000 & R10 & 50,000 & $10,000,000$ \\
\hline
\end{tabular}

Source: Collected from the Division of Planning and Investment, 2018. 
Thatluang and Thongkhankham villages. The process has been implemented by exchanging land use rights between state agencies and private enterprises. In practice, the government transfers urban land rights to private entities to invest in the construction of the state agency buildings at new location. For community resettlement, it is conducted through compensation for affected assets such as land, buildings, yields and others. Those are a key part of urban development to reduce congested traffic, slum and to improve cityscape and infrastructure services. Nevertheless, capitalization in Vientiane has seemed to allow local private sector and transnational corporation to seek economic benefits from selling commodities, property and services. While the state role in spatial management for commodity production and service is de-territorialized, but the government has been able to (re) territorialized the state control over natural resources by making concession agreements. If investors do not follow the contract, the land concession rights will be cancelled. For example, the land concession on Nongchan brought to gather Korean and Vietnamese investor to construct a water park. While they built some initial infrastructure, but had to suspend activities for many years due to a lack of capital. Eventually, the government cancelled the contract and transferred this land to another investor, including some from Yunnan province of China.

\section{The Main Actors and Beneficiaries in the Implementation of the Urban Development Vision}

The urban development vision of Vientiane is implemented by several sectors whether public, private or people, including international development agencies. The state and private sectors both local and foreign are the main actors in this process. They include central government, local authorities and local and foreign property developers. The bulk of investors are from China, who play a key role in implementing such projects, together with local investors. It has seen a relative explosion of housing construction, much of it financed by China. Meanwhile, financial and technical assistance from ADB, JICA, KOICA, UN-HABITUS, AFD and NEDA is perceived as carrying major significance in the development process. A further actor here is Vientiane City Office for Management and Services, which is currently a part of the Vientiane administration Authority. Khamphet (2018) explained that the office plays an important role in managing sanitation, drainage, decoration, waste disposal, and maintenance work in the urbanized area. In addition, it also plays an important role in implementing the urbanization strategy [38].

Beneficiaries from this process can be summarized as follows: 1) Direct beneficiaries include the state and capitalists (investors), entrepreneurs, and upperand middle-class households. Many of the investors and entrepreneurs involved in large-scale land concession projects are Chinese, Vietnamese, and Korean, with some Lao private corporations and 2) Local people, especially those belonging to middle- and some lower-classes, benefit indirectly from improved in- 
frastructure services such as roads, public transportation, health care centers, education, sport centers, public park, sanitation systems and various facilities. However, with a growing scarcity of land and a consequent rise in its price in the inner urban zone, has pushed some young and poor income families have been pushed to relocate and build new houses in the outer area. In contrast, some political elites, investors, entrepreneurs, foreigners, upper- and middle-class households have moved into the urban central area. These households use financial power to buy pieces of urban land with good locations for speculation or to resettle, accessing improved infrastructure services and facilities. Economic and natural capital are accumulated for their families. Meanwhile, poor class households are pushed to resettle in the outskirts of the city both through voluntary and involuntary actions.

\section{Conclusions and Limitation}

Urban space in Vientiane has been driven by different players. During the colonial period, urban space was rebuilt many times. From 1893-1953, French colonial authorities restored, planned and redeveloped the city. In post-colonial time, the city was repaired, designed and developed further through the construction of roads, offices and residences from inner to outer urban zones. The urban development vision has adjusted to global development trends, especially principles of sustainable development. The vision has been implemented by several means such as marketization, privatization, and neoliberalization using the urban master plan and urban development strategies. In the early 2000s, neoliberal policy has been used in the urban development planning, linking the city into structures of global capital. Converting land into capital is an economic policy that utilizes natural resources for development through the granting of concessions. The policy was initially designed to reduce the spending of the state on infrastructure development.

As a result, many state agencies have been relocated to suburban and outskirt areas. Similarly, some urban communities have been relocated from urban sites. The process was approved by the central government with participation from local authorities, bureaucrats, local people and investors. All methods have transformed the urban landscape, local livelihoods and state land under planning for urban redevelopment. The shift has resulted both in direct and indirect beneficiaries. The state authorities and property developers are as direct beneficiaries. Local people, especially middle and lower classes have indirectly benefited from the infrastructural improvements. However, private companies have monopolized their economic interests in public space based on frameworks of land concession contracts. This situation relates to Marx's theory of primitive accumulation and Harvey's theory of accumulation by dispossession. In short, the urban development process in Vientiane involves cooperation among the government, local private and Chinese state-backed enterprises. For future research, there remain many issues in Vientiane. These include urban governance, 
public space management, urban gentrification, everyday life and the rights to the city. Without further research into these areas, it will not be possible to understand many urban-related questions. At the same time, I would like to recommend that public policy-makers and related state authorities promote the participation of different stakeholders in decision-making process.

\section{Conflicts of Interest}

The author declares no conflicts of interest regarding the publication of this paper.

\section{References}

[1] Hiller, H. (2004) Political Economy Paradigm.

[2] Haque, K. (2012) The Political Economy of Urban Space: Land and Rural Estate in Dhaka City. Institute of Governance Studies (IGS), BRAC University, IGS Working Paper Series No. 03/2012, Dhaka.

[3] Smith, N. (1984) Uneven Development; Nature, Capital, and the Production of Space. Blackwell.

[4] Soja, E. (1989) Postmodern Geographies: The Reassertion of Space in Critical Social Theory. Verso, London and New York.

[5] UNDP (2020) Sustainable Cities and Communities. http://www.la.undp.org

[6] Castells, M. (1977) The Urban Question: A Marxist Approach. The MIT Press, Cambridge.

[7] James, P., Holden, M., Lewin, M., Neilson, L., Oakley, C., Truter, A. and Wilmoth, D. (2013) Managing Metropolises by Negotiating Mega-Urban Growth. In: Mieg, H. and Töpfer, K., Eds., International and Social Innovation for Sustainable Urban Development, Routledge, Abingdon-on-Thames.'

[8] Castells, M. (2002) The Information Society and the Welfare State: The Finnish Model. Oxford University Press, Oxford.

[9] Harvey (2000) Space of Hope. University of California Press, Berkeley.

[10] Castells, M. (1989) The Information City: Information Technology, Economic Restructuring, and the Urban Regional Process. Blackwell, Oxford.

[11] Sassen, S. (1991) The Global City: New York, London, Tokyo. Princeton University Press, Princeton.

[12] Sassen, S. (2005) The Global City: Introducing a Concept. The Brown Journal of World Affairs, 11, 27-43.

[13] Shi, G., Zhou, J. and Yu, Q. (2012) Resettlement in the People's Republic of China. In: Tortajada, C., Altinbilek, D. and Biswas, A., Eds., Impacts of Large Dams. A Global Assessment, Springer, Berlin, 219-242.

[14] Harvey, D. (2004) The New Imperialism: Accumulation by Dispossession. Socialist Register, 40, 63-87.

[15] Harvey, D. (2005) A Brief History of Neoliberalism. Oxford University Press, New York.

[16] McGee, T. (2009) Interrogating the Production of Urban Space in China and Vietnam under Market Socialism. Asia Pacific Viewpoint, 50, 228-246. https://doi.org/10.1111/j.1467-8373.2009.01395.x

[17] McGee, T., Lin, G., Marton, A., Wang, M. and Wu, J.P. (2007) China's Urban Space: 
Development under Market Socialism. Routledge, Abingdon-on-Thames!. https://doi.org/10.4324/9780203934791

[18] Tsenkova, S. (2006) Beyond Transitions: Understanding Urban Change in Post-Socialist Countries. In: The Urban Mosaic of Post-Socialist Europe: Space, Institutions and Policy, Springer, Berlin, 21-50. https://doi.org/10.1007/3-7908-1727-9

[19] Zhang, L. (2001) Strangers in the City: Reconfigurations of Space, Power, and Social Networks within China's Floating Population. Stanford University Press, Stanford.

[20] Hayward, D. (2017) Understanding Institutional Challenges for Urban Planning in Vientiane, Laos. Urban Climate Resilience in Southeast Asia Project.

[21] Manotham, H. (2010) The History of Urban Planning of Vientiane City. Lao Version.

[22] Sayarath, C. (2005) Vientiane, Portrait d'une ville en mutation. Les, Paris.

[23] JICA (2011) The Project for Urban Development Master Plan Study in Vientiane Capital. Japan International Cooperation Agency (JICA), Tokyo.

[24] Sayarath, C. (2003) Vientiane architectures civiles et religious. Vientiane cahiers de I'Ipraus/E'ditions Recherches (French Language).

[25] Sisoulath, B. (2003) Vientiane, Stratégie Du Développement Urbain: Processus et Acteurs de L'urbanization dans la Capitale, de la République Démocratique Populaire Lao. Thèse pour le doctorat de géographie Université De Paris-X-Nanterre. République française.

[26] Insisiengmai, A. (2017) Deputy Director of Public Work and Transport Institute, Vientiane. Interview.

[27] Choummanivong, S. (2018) Deputy of Section of Housing. Interview.

[28] Phouvong (2018) Deputy Section of Public Work and Transport of Vientiane, (2017, June 7). Interview.

[29] Sharifi, A., Chiba, Y., Okamoto, K., Yokoyama, S. and Murayama, A. (2014) Can Master Planning Control and Regulate Urban Growth in Vientiane, Laos? Landscape and Urban Planning, 131, 1-13. https://doi.org/10.1016/j.landurbplan.2014.07.014

[30] Vientiane Administration Office (2015) Political Report at 5th Part Committee of Vientiane Administration Authority.

[31] Aphaylath, K. (2017) Vice Mayor of Vientiane, (2017, March 15). Interview.

[32] Lengsavad, S. (2013) [Deputy Prime Minister and President of the Lao National Committee for Special Economic Zones (NCSEZ)] Claimed at the 8th Congress of LPRP (Coated in KPL (Lao News Agency)).

[33] Bannavong, P. (2017) Head of the Division of Planning and Investment. Coated in Vientiane Administration Office, 2015.

[34] Nolintha, V. (2011) Cities, SEZs and Connectivity in Major Provinces of Laos. In: Ishida, M., Ed., Intra- and Inter-City Connectivity in the Mekong Region, BRC Research Report No. 6, Bangkok Research Center, IDE-JETRO, Bangkok.

[35] Pathammavong, B., Kenney-Lazar, M. and Sayaraj, E. (2017) Financing the 450 Year Road: Land Expropriation and Politics' All the Way Down in Vientiane, Laos. Development and Change, 48, 1417-1438. https://doi.org/10.1111/dech.12339

[36] Khoudphaithoun, S. (2016) (Coated in KPL, 2016). Vientiane Governor.

[37] Malabandith, K. (2015) Head of the Finance Division Add Coated in Vientiane (Coated in Vientiane Administration Office, 2015). 
[38] Khamphet (2018) A Senior Official and Technocrat from VCOMS (June 8). Interview.

\section{Acronyms}

$\begin{array}{ll}\text { AFD } & \text { Agence Française de Développement (French) } \\ \text { BOO } & \text { Build-Own-Operate } \\ \text { BOOST } & \text { Build-Own-Operate-Subsidize-Transfer } \\ \text { BOOT } & \text { Build Own Operate Transfer } \\ \text { BOT } & \text { Build-Operate-Transfer } \\ \text { BTO } & \text { Build-Transfer and Operate } \\ \text { PCCPTB } & \text { The Party Central Committee's Propaganda and Training Board } \\ \text { LFTU } & \text { The Lao Federation of Trade Unions } \\ \text { LNTA } & \text { The Lao National Tourism Agency } \\ \text { MLSW } & \text { Ministry of Labor and Social Welfare } \\ \text { MOJ } & \text { Ministry of Justice } \\ \text { NEDA } & \text { Neighboring Countries Economic Development Cooperation } \\ & \text { Agencies } \\ \text { PPP } & \text { Public-Private Partnerships } \\ \text { VDICT } & \text { Vientiane Division of Information, Culture and Tourism }\end{array}$

